\title{
And that's the way it is
}

\author{
by Paul McKellips
}

When I was growing up in Wisconsin, Walter Cronkite and the CBS Evening News was a religious experience. Supper, as my parents called it, was served promptly at five oclock, dishes were washed and we were in our seats and ready for the CBS News theme music by five-thirty.

If Walter didn't say it, then it just wasn't so. He reminded us of that fact at the end of every newscast: “... and that's the way it is."

The New York Times stood as the flagship of print journalism. According to the newspaper's motto, first used on 25 October 1896, "all the news that's fit to print” was inside.

In the post-modern model of journalism, journalists, editors and publishers upstream prepared, packaged and distributed the news downstream through transmission towers and paperboys. Readers, listeners and viewers simply consumed the news. For 125 years, hard-hitting reporters and professional journalists worked their beats, developed sources, asked probing questions and produced news with an eye toward objectivity. But somehow these purveyors of information, whom we believed to possess unfailing instincts for news, apparently missed the coming of the Internet.

On 30 April 1995, when final restrictions were lifted for carrying commercial traffic, the World Wide Web didn't just change journalism: it ignited a revolution. The oldworld journalistic clarity of upstream news being delivered to downstream consumers died.

TV transmission towers and paper routes have been replaced with free digital distribution. The people, once an audience of readers and viewers, have become crowds of users and publishers. Mass media has become micro-media.

Viewership for evening network news has declined for 30 years straight. Newspaper advertising revenue and circulation numbers have fallen dramatically in the last decade, and the numbers of writers and editors have plummeted since 2006.

\section{Great news is a great story- salacious gossip, national conspiracies, government secrets and lurid mysteries.}

Last summer, CNN reported that the Supreme Court had thrown out the individual mandate on the Affordable Care Act. But that was wrong. A citizen blogger was the first reporter to get it right-and his report was viewed one million times within an hour. Where were the New Yorkbased journalists when Bernie Madoff's Ponzi scheme was running amok? It took a citizen journalist doing investigative snooping to bring down that house of cards. The stories of the Arab Spring and the Syrian revolution are being covered in first-person accounts by citizen journalists with iPhones.

The professional news-gatherers of our time all missed the coming of the digital revolution and the impact it would have on the people. Perhaps they weren't the only ones.

Today's science and research communicators seem to think that a vertical news hierarchy still exists. We still send out press releases, hire PR firms to pitch complex stories and post pre-packaged news items on our home pages, hoping that a professional journalist will see our press release, decipher a white paper or read something intriguing on our home page and then write a flattering, truthful story about us. We missed the memo pointing out that nowadays, news organizations search, scour and source the web for the buzz that crowds are already talking about. Our university and corporate communications departments are under immense internal pressure to create mass media exposure through an old-world news industry that no longer exists instead of embracing the new opportunities in micro-media.

News is about storytelling. Great news is a great story-salacious gossip, national conspiracies, government secrets and lurid mysteries. And what, pray tell, is the essence of basic science? Uncovering mysteries. Every day we discover new evidence and move closer to solving the mysteries of disease and dreadful conditions. Every day we add another clue gleaned from a worm, fruit fly, mouse or zebrafish.

That's a great story! That is news.

We just need better presentation. Maybe we should stop packaging biomedical research news like it's 1972 and write shorter, more compelling stories about discovery. Maybe we should stop churning out press releases in search of journalists who have left the newsrooms and now surf the web looking for news in their bedrooms. Maybe we should stop trying to control 'all the research news that's fit to print.' We might just turn on an entire new world of users and publishers.

When we unleash our scientists, researchers and lab animal specialists to blog, post, comment and publish, we will reach the crowds with transparency. The people are hungry for mysteries being solved. A global buzz will ripple through every culture where disease respects no border, creed or economic status.

Global buzz-not press releasesgenerates earned media coverage. And that, my friend, is the way it is. 